\title{
Difficulties for eGovernment promotion in Serbia: The analysis of eUprava Portal ${ }^{1}$
}

\author{
Norbert Merkovity ${ }^{2}$ \\ University of Szeged/National University of Public Service, Hungary
}

\section{doi:10.5937/comman1327005M}

\begin{abstract}
Summary: We want to make clear there are no recipes for good communication of eGovernment. Good solutions, brave attempts to involve the public in eGovernment are the only examples what we can follow in this specific area of government. We will introduce theories and analysis of eGovernment environment in this article, which may be useful in designing a promotion and communication plan for the portal eUprava as a central site of Serbian eGovernment. After the general characteristics of society and communication in the world of eAdministration, we will introduce a dilemma, which strains between the good government and good governance. One section will be about a theory on good governance, the Digital Era Governance (DEG) and one on the barriers of the communication. The last section will analyze and discuss the eUprava portal. We will use PEST and SWOT analysis to detect the most urgent problems for the possible promotion of the portal.
\end{abstract}

Key words: eAdministration, eGovernment, eUprava, good governance, DEG, communication plan

\section{General role of communication in the eAdministration}

"To realize a national communication strategy, strong leadership is required" (UN, 2012: 56). The strong leadership could bring together political

\footnotetext{
1 The full version of this article was written to the project "Support to e-Government development in Serbia”. Technical assistance project financed by EU (reference no. EuropeAid/129913/C/SER/RS), implemented by AAM Consulting Ltd.

2 merkovity@juris.u-szeged.hu
} 
and NGO actors, ministries and other stakeholders. This can help for the communication and promotion plan, as well. The leader(s) could identify the communication barriers and develop a plan for dissemination and popularization of the eGovernment. These circumstances can help to communicate success stories. A new environment, like eGovernment needs success stories, because these positive messages can bring new costumers/users to eGovernment portals. Although some global trends must take into account during the development of a promotion/communication strategy (see Szittner, 2011):

- The rate of digital literacy has increased in last decade. However, the illiteracy changed to considerably less rate, the ratio has not decreased significantly (see Karabulut et al., 2009).

- The digital divide is still widening. It is not wider, but it is getting more deeper (see Pew Internet, 2012).

- The role of direct connection to the internet and the personal experience are important. Nothing is better to increase internet penetration than the personal experience (see Schlosser et al, 1999)

- The secondary digital inequalities are becoming more critical. Cleavages within the users, or in other words the secondary digital divide is growing. Large number of internet users is using it passively; they still choose traditional communication channels to be in contact with family, friends, administrations, etc. (see Mominó, 2007).

\section{Good government - good governance}

After the fall of the Berlin Wall, Central-Eastern and South-Eastern European former communist-socialist states had radically renew their previous government philosophy. The applied model was the solution of Western European democracies, commonly known as New Public Management (NPM). The philosophy of the "good government" becomes stronger. However, some differences seem to remain, the debate between the "good government" versus the "good governance" is still here to stay. As a rule, we can say that the government is still the central element of the "new democracies" administrations, which strengthen the theory of the "good government". The idea of "good 
governance" changes from country to country, but it only appears on the lower level of administration, or in the governments' communication. However, it has become clear that the governance models of Western-style democracies need a revise. The good government and the governments' NPM model are not able to involve the citizens in the discussions and debates about the state, laws and administration. Moreover, the confidence in state authorities and administrations is decreasing (Merkovity, 2011).

" 'Citizen participation' - understood in the broad sense of 'engaging with public authorities to assist them in the development of policies that promote social justice' - continues to be a dangerous occupation in many of our modern democracies. In most countries however, [...] public participation turns out simply to be 'almost irrelevant': its practical use is so low that few citizens feel motivated to make any use of it. To comprehend why this happens, we need to consider that participatory arrangements have always played a subordinate role within representative democracies' decision-making mechanisms. Representative democracy, meanwhile, is best understood as a form of 'thin democracy' (Barber, 1984), which does not rely much on citizens for actual decision-making, except perhaps on election day" (Prieto-Martin et al., 2012: 63).

The European Union recognized this threat and in its Declaration on eGovernment writes the following:

"Citizens and businesses [will be] empowered by eGovernment services designed around users needs and developed in collaboration with third parties, as well as by increased access to public information, strengthened transparency and effective means for involvement of stakeholders in the policy process" (EC, 2009: 2).

This declaration also set the base for a new European eGovernment Action Plan 2011-2015 (EC, 2010), which first priority is precisely to promote "user empowerment" and the collaborative production of innovative services.

However, eGovernment did not meet the expectations. The latest articles about eGovernment had better prefer to use the expression "Transformational Government" when talking about the digitalization, IT and ICT use in the public administration. The following table shows the differences between the eGovernment and the Transformational Government. 
Table 1: The eGovernment approach and the Transformational Government approach (Borras, 2012: 28-29)

\begin{tabular}{|c|c|}
\hline eGovernment & Transformational Government \\
\hline Government centric & Citizen centric \\
\hline Supply push & Demand pull \\
\hline $\begin{array}{l}\text { Government as sole provider } \\
\text { of citizen services }\end{array}$ & $\begin{array}{l}\text { Government also as convener of } \\
\text { multiple competitive sources of citizen } \\
\text { service }\end{array}$ \\
\hline Unconnected vertical business silos & $\begin{array}{l}\text { A virtual business layer, built around } \\
\text { citizen needs, operates horizontally } \\
\text { across government }\end{array}$ \\
\hline $\begin{array}{l}\text { "Identity" is owned and managed by } \\
\text { government }\end{array}$ & $\begin{array}{l}\text { "Identity" is owned and managed by } \\
\text { the citizen }\end{array}$ \\
\hline $\begin{array}{c}\text { Public data locked away within govern- } \\
\text { ment }\end{array}$ & $\begin{array}{l}\text { Public data available freely for reuse by } \\
\text { all }\end{array}$ \\
\hline $\begin{array}{c}\text { Citizen as recipient or consumer of } \\
\text { services }\end{array}$ & $\begin{array}{c}\text { Citizen as owner and co-creator of } \\
\text { services }\end{array}$ \\
\hline Online services & Multi-channel service integration \\
\hline IT as capital investment & IT as a service \\
\hline Producer-led & Brand-led \\
\hline
\end{tabular}

The table indicates that the Transformational Government is more user friendly than eGovernment. However, other theories exist, as well, which are developing more user-friendly government, the good governance. One is the Digital Era Governance, represented in the next section.

\section{Digital Era Governance}

The Digital Era Governance (DEG) submitted the thesis that the IT is not simply an element of administrative work, but it is an operative fundament. Since technology changes behaviors and structures, it can generate fast culturechange, as well. The methods of operation and the organizations have to accommodate to the altering social and technological environment.

The three main points of interference are the reintegration of services, the demand-based holistic approach, and the extensive digitalization of administrative operations (see Dunleavy et al., 2006; Dunleavy \& Margetts, 2010). The key elements of the DEG are: 


\section{- Reintegration:}

- Reverse of agencification and disruption - with ceasing and mergers;

- Joined-up governance (JUG) - horizontal action-organizations;

- Re-governmentalization - taking back public tasks from the private sphere;

- Strengthen up and revival of central processes;

- Large-scale decrease of expenses of production;

- Re-planning of „back-office” functions, re-engineering;

- Concentration and specialization of procurements;

- Shared services on base of a mixed economy;

- Network-simplification, creating "small worlds";

\section{- Demand-based holism}

- Interactive information-giving and searching;

- Restructuring on the ground of demand or client;

- Administration in one step, ask-once processes;

- Data warehousing;

- End-to-end service re-engineering;

- Agile administrative processes;

- Sustainability;

\section{- Digitalization}

- Providing electronic services and e-Administration;

- Utility computing;

- New form of automated processes (zero touch, RFID);

- Radical disintermediation;

- Channel streaming and client segmentation;

- Directed and mandated decrease of transactional channels;

- Facilitating isocratic administration;

- Open-book government. ${ }^{3}$

3 For more information on DEG see: Merkovity N. (2011). A New Public Managmenttől a Digital Era Governance-
ig: Kormányzás paradigmák a nyolcvanas évektől a millenniumi évekig [From New Public Management to Digital 


\section{Barriers of communication}

One can understand barriers of eGovernment's usefulness communication if we want to analyze digital exclusion, not inclusion. Van Dijk (2005) argues that distinguishing between material, skills, motivational, and usage access is vital in studying digital exclusion, and research on digital exclusion generally identifies four areas from which one can be excluded: access, skills, attitudes, and types of engagement. In Helsper's model, important aspect is that social impact mediators (specifically, individuals' access, skills and attitudes) may mediate the influence of offline fields of exclusion on digital fields of exclusion (Helsper, 2012). Conversely, digital impact mediators (specifically, the relevance, quality, ownership, and sustainability elements of different types of digital engagement) mediate the influence of digital fields on offline fields of exclusion. Figure 1 shows, how the corresponding fields model imagines that the four fields from which an individual can be excluded offline have corresponding fields of exclusion in the digital world. It also depicts how social impact factors mediate the impact of offline exclusion on digital exclusion and how digital impact factors mediate the impact of digital exclusion on offline exclusion. Importantly, although the fields are conceptually distinct, in practice, they are often linked and their effects compound each other.

Figure 1: Basic corresponding fields model (Helsper, 2012: 406)

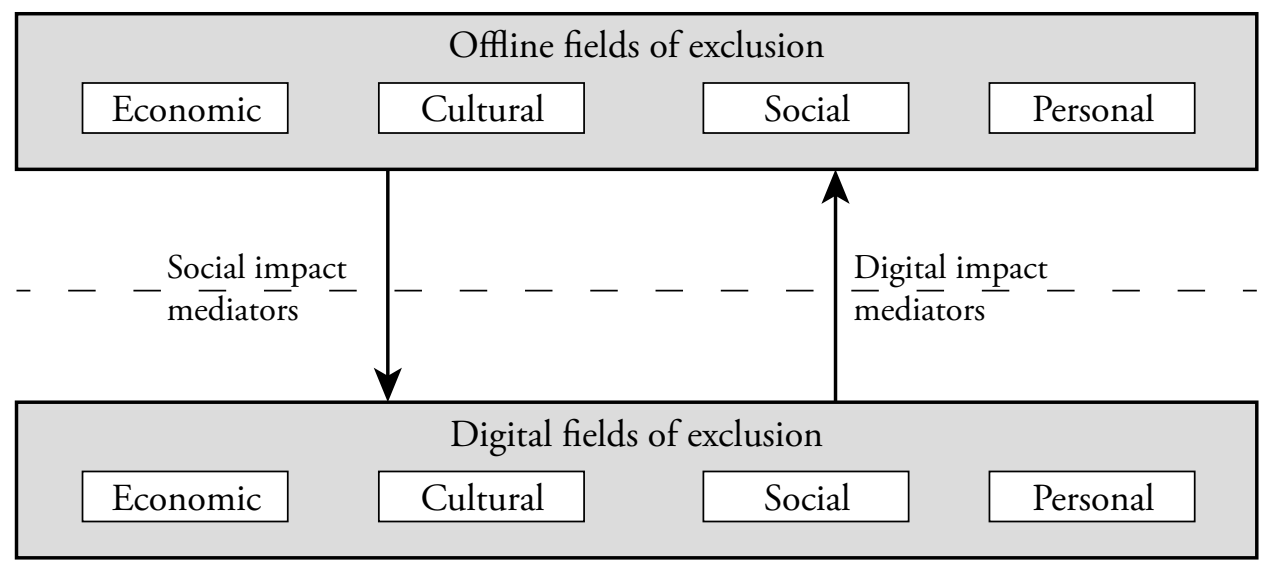

Era Governance: Governance paradigms from the eighties until the Millennium years]. De Iurisprudentia et Iure Publico, Jog-és Politikatudományi Folyóirat, 20115 (3), 108-112. 
Although access, skills and attitudes have all variously been targeted by digital inclusion initiatives, these are insufficient, and research and interventions should recognize the importance of people's practical engagement with ICTs. As social exclusion, digital exclusion can be defined and measured in a number of ways, and much could still be learned from the work of economists and sociologists who have analyzed social exclusion. Within the corresponding fields model, digital inclusion is less determined by whether someone uses technologies and more by whether the nature of their use enhances their life. This statement is not uncontroversial. Some argue that what people eventually do or do not do with ICTs is no one's business but their own, as long as they have the skills and access to do so. However, just having the right access, skills and attitudes without actually making broad use of ICTs would surely not improve digital and, therefore, offline exclusion (Witte \& Mannon, 2010). The model thus assumes no single form of digital inclusion, and takes the normative stance that engagement with one type of digital resource should not be ranked higher than engagement with another. One can be more or less socially digitally included but this is not better or worse than being economically digitally included because economic, social, cultural, and personal resources are all fundamental to well-being and full participation in society.

The next sections discuss three social impact mediators.

\section{Access}

Without access, no one can use the internet or other ICTs, therefore access is the most basic mediator between offline and digital fields of exclusion. Any operationalization of access to ICTs should go beyond having some kind of access somewhere incorporating aspects like quality, mobility and ubiquity. For example, home access to ICTs offers more freedom to use and to develop digital skills through informal learning than access in other locations. Home access can therefore be used as an indicator of high-quality access (Mumtaz, 2001). Similarly, in the case of the Internet, always on and broadband access should lead to a higher quality experience and broader use. A high number of access platforms, such as PCs, laptops, games machines, and smart phones, as well as a greater mobility in accessing content, for example through wireless or $3 \mathrm{G}$ connections, are indicators of ubiquitous access (Georgiou et al., 2010: 21). 


\section{Skills}

Certain skills are required for the handling of ICTs and the internet. These skills include knowing how to turn a device on or off but are arguably broader than this. Zillien and Hargittai argue that these skills come with but are not the same as extensive use of applications and platforms (Zillien \& Hargittai, 2009). Skills should be measured on a basic technical and operational level, as well as in relation to critical and social skills in working with communication technologies. Creative uses of ICTs are also central, as are the skills that allow for the critical evaluation of trustworthiness and accuracy of content and sources. Livingstone and Helsper argue that the best measures of skill level are those that ask for expertise in a variety of specific tasks combined with measures of overall self-efficacy (Livingstone \& Helsper, 2010). The specific measures related to technical, social, creative and critical skills would predict different uses of ICTs more succinctly. Basic access to and use of ICTs might be more strongly associated with general self-efficacy.

\section{Attitudes}

Attitude formation in relation to the usefulness and dangers of ICTs goes beyond perceptions of personal skills. Computer anxiety, for example, is the apprehensions one has regarding use of the ICTs in general, relating to the effect they have on society, freedom and morals. Operationalization of ICT attitudes should probably include opinions about the availability, appropriateness, and regulation of content, as well as attitudes about effects of problematic content such as violence, sexual, political, and commercial content on vulnerable groups or society in general. Attitudes about improvements in productivity, effectiveness and changes in social interaction are also part of this spectrum and can be linked to corresponding offline resources.

These social impacts warn us, that offline and digital exclusions are interdependent. For instance, the offline culture and digital culture are interacting with each other. This works similarly in every society, therefore the solutions could be similar, as well. 


\section{Analysis of the portal eUprava}

The site eUprava is central portal of the Serbian eGovernment environment. Taking into the account the history of the establishment and the circumstances of the portal it is clear and transparent, a good produce. The eUprava should serve as the central of information and communication, interaction and transaction portal of Republic of Serbia's government, but it has lot to do to achieve this goal. ${ }^{4}$ At the same time, the communication and promotion achievements in the world of eGovernments are not measured with the same standards as the impregnation in government's "electronic life"; it complies with the objectives set by strategy and expectations. The portal is far away from these goals, while also boasts a number of important results. However, some fundamental, interrelated aspects of enforcement are missing, which can significantly improve the quality of the portal's communication. Briefly summarized these may include:

- Enforcement of comprehensive content and navigation logic,

- Intensive service management,

- Intensive interface management,

- Full and continuous usability control,

- Rethink the characteristics of the main page,

- Validation of the authentication strategy,

- Medium-term communication strategy (in addition to the short-term strategic agenda).

The following parts of this section would discuss these above-mentioned points. After the general observations and the trends of use eServices, particularly the eUprava site, the SWOT and PEST analysis and the stakeholder identification and analysis should show the possible strengths and weaknesses of the portal. This chapter will highlight the past and present communication strategies of the portal, it will show several desirable paths to design a better promotion and communication plans of the portal eUprava. Therefore, this chapter is not only a simple analysis of the eUprava portal and recommendation for the future communication strategies, but a gap analysis, as well.

\footnotetext{
${ }^{4}$ E.g. the descriptions of cases are incomplete; it does not help enough the customers to find the information they need. Similar is the situation with the information on legislation, which is an essential element of legal certainty.
} 


\section{General observations}

Well-known fact is that the public side's demand for eServices is not the same for all institutions. There are institutions against which was expected the possibility of electronic administration long time ago (governmental administrations, telephone companies), while other needs were less articulated (shopping centers, non-governmental organizations). It is clear that the demand against governmental and non-governmental organizations to have the possibility of electronic administration (eAdministration) is increasing. However, this does not mean automatic use of eServices from the side of the public. This is the case especially with the governmental eServices, because the public is used to do these services on traditional way, the citizens have more confidence in face-toface administration. Other reasons can be behind the lack of use, as well:

- The access capability would clearly define the relation to electronic administration, those, who have access, would be more enthusiastic in use of eAdministration than those who do not have access. From the perspective, those, who do not have access, could be enthusiastic in use of eAdministration if they learn the use of eServices. This means that today "non-users" of eServices need motivation tools to get involved in eAdministration.

- The practice of administration was almost exclusively based on the personal presence in the past, the accountability, the personal knowledge of the administrators sometimes were more than the knowledge of the legal and administrative status of the citizen.

- The growth of eAdministrative facilities often does not coincide with the expansion of internet subscription. Citizens who exclude the possibility of eAdministration for most, has already been away from the internet.

These reasons are warning us that in order to make a functioning promotion/communication plan we have to accept that some citizens will reject the possibility of eAdministration.

\section{Trends of using eServices in Serbia}

The survey of the Statistical Office of the Republic of Serbia from 2012 shows $47.5 \%$ of the households have internet connection and $30.9 \%$ of the 
internet users use internet services at least once in the last three month before the survey, instead of establishing personal contacts or visiting public institutions or administration bodies (Statistical Office, 2012). This result is showing a growth of $13.6 \%$ from 2011 , when only $17.3 \%$ of internet users use eServices offered by the state (Statistical Office, 2012). The growth between the two data is promising, over 840,000 persons use electronic services of public administration in 2012. However, the compositions of data are not encouraging, see the following two figures:

Figure 2: For which of the following public administration services did you use the internet? (Statistical Office, 2011)

Obtaining information from public authorities' websites

Downloading official forms

Sending filled in forms

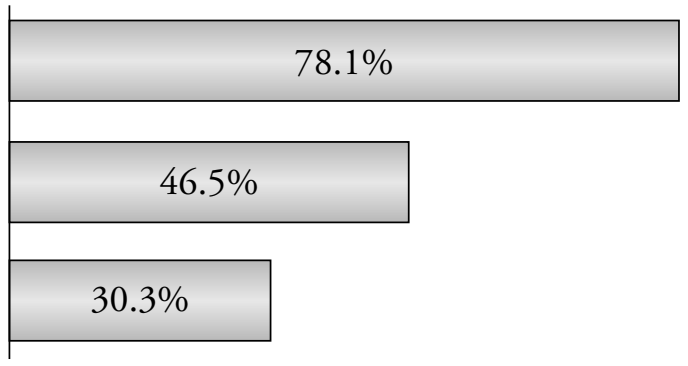

Figure 3: For which of the following public administration services did you use the internet? (Statistical Office, 2012)

Obtaining information from public authorities' websites

Downloading official forms

Sending filled in forms

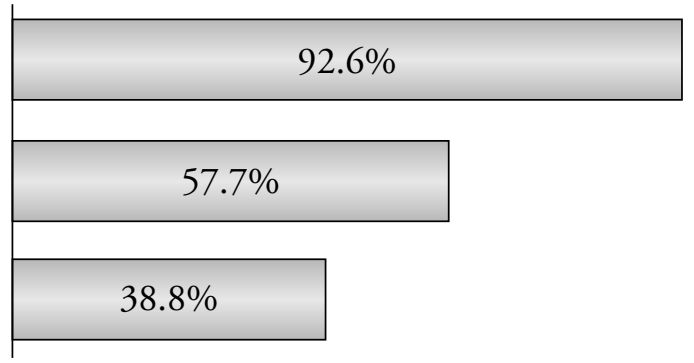

The figures show that the number of those citizens who obtained information from public authorities' web sites increased a lot, from $78.1 \%$ to $92.6 \%$. This means that the simple knowledge acquisition increased in highest percentage. The downloading official forms and sending files in forms are higher in 2012 than in 2011, but the growth is much lower than in the case of gathering 
information from authorities' sites (11.2\% and 8.5\%). Altogether, the numbers are encouraging, but there is still room for improvement. These numbers have effect on the use of the portal of eUprava.

The portal's five most frequently used services are:

1. Booking an appointment to apply for identity card and passport

2. Booking an appointment to apply for vehicle registration

3. Purchase a birth certificate

4. Purchase a proof of citizenship

5. Renewal of vehicle registration

The statistics from Google Analytics for September, October and November of 2012 indicates that 76,752 people visited the portal eUprava, from which $63.48 \%$ were new visitors and $36.52 \%$ had already been on the portal. Altogether, they made 108,080 visits and 654,367 page views. It means that the average visitor opened 6.05 subpages. The average visit duration was 4 minutes and 37 seconds.

According to the report of the Directorate for Digital Agenda, in November of 201287,289 active individuals were registered on the portal, and from them 87,104 were registered as an individual (not as a representative or agent of a company or an institution). In addition, the portal had 30 registered legal persons.

\section{SWOT and PEST analysis of the portal eUprava}

More than 350 services are available on the portal from around 130 bodies. The key functions of the portal are the following:

- The use of qualified digital certificates for identification and electronic signature,

- Application for electronic time stamp,

- Horizontal services,

- Distributed editing service and processing of requests,

- Accepting payments with electronic payment order or credit card,

- Email and SMS notifications to the costumers. 
The key challenges are the following for the portal eUprava:

- Small number of services are in use by the public; the ePayment is not perfect,

- Some authorities have not set up their services on the portal,

- Services do not use the full potential of the portal,

- There are delays in the processing of services (usually at the local level, but this could happen because of maintenance work during the workday on the portal).

In this section SWOT analysis is employed to discuss strengths (S), weaknesses $(\mathrm{W})$, opportunities $(\mathrm{O})$ and threats $(\mathrm{T})$ of the portal eUprava. Each of the four components of SWOT analysis is further examined according to PEST analysis, which is referring to political $(\mathrm{P})$, economic $(\mathrm{E})$, social $(\mathrm{S})$ and technological (T) determinants. In the first part, we will analyze the eGovernment environment and in the second part the eUprava portal, while the 4.4 chapter will further analyze the weaknesses and threats of the portal.

\section{Strengths}

The strengths of Serbia to develop and maintain eGovernment lie in the government's recognition of a need for a portal. This is an important political determinant in the PEST model. The government heard the call of the time and this applies to previous governments from the Public Administration Reform Strategy (2004), as well. This characteristic created stability that helps all interested stakeholders to adopt eServices. These bodies are building up a working legal foundation that could create a secure online environment for users. Thus, the Serbian government can strengthen its relationship with the public. The government has encouraged both the public and private sectors to contribute to the growth of eUprava by introducing more than 350 services on the portal.

Regarding economics, Serbia - as most of the countries in Europe - is facing difficulties. Despite the austerity measures, the further development of eGovernment portal is still one of the priorities. This gives stability and confidence in a further development of the portal. However, political stability and appropriate policies are not enough to create an awareness of eGovernment. It needs sufficient funds to finance and enhance the system. 
Among the social strengths of Serbia, the educational system is one that produces a well-educated workforce. There are many domestic corporations, which could be engaged in eServices to cut costs and to improve their operations. They need employees with IT proficiency and the ability to learn fast. A tech-savvy population and a well-educated IT labor force can participate in eGovernment projects and can use these services effectively.

Technologically, Serbia is not a high-tech based economy, but it has a wellprepared infrastructure and it could to contribute to the rapid development and deployment of eServices. "Technology, IT, ICT or other inventions become out-of-date quickly. Thus, continual innovation and creativity for better products and processes helps organizations and countries tackle the problems of obsolete technology" (Ha \& Coghill, 2006: 118).

\section{Weaknesses}

Serbia's eGovernment environment still faces some weaknesses regarding the political determinant. Traditionally, the public believe that the Serbian Government "always wants to introduce new methods and new approaches to earn more from the public. This belief may cause people to hesitate in trying eServices. Other weaknesses are the public feelings of insecurity and concern about making mistakes. These issues discourage people from tapping into eServices" (Ha \& Coghill, 2006: 118) and increase a fear from the "Big Brother". There is still lot to do on data protection and on introduction of EU standards.

In terms of the economy, Serbia has still low tradition of online banking. Furthermore, the rate of unemployed people is high, therefore many people have no credit card and they are not able to pay online purchases. This may emerge as one of barriers.

Socially, "a large portion of blue-collar workers and the older generation are still computer illiterate. Others may find it difficult to follow instructions on the internet or may be discouraged by computer-related problems." (Ha \& Coghill, 2006: 118). Some people may not have the chance to access information online. However, this weakness could originate from the different mentality of the citizens. There is a difference in computer and internet knowledge, skills and even in people's motivation between North-Serbia and South-Serbia. Citizens from the northern part of the state are more ICT centric than the public from the southern part. That is why the services of eGovernment must be alike, simple, easy to learn and transparent. 
"Technologically, less IT-savvy people and the older generation are afraid of computer related problems. Some government websites are not user friendly. Thus, these websites attract few people. Time is another issue." (Ha \& Coghill, 2006: 118-119) Internet users may have to spend a lot of time on the internet, because the internet connection is slow, especially in rural parts of the country. We must acknowledge that the mode of internet connection is changing right in front of our eyes.

\section{Opportunities}

In spite of the above-mentioned shortcomings, there are many opportunities for eGovernment (see: Ha \& Coghill, 2006). The political willingness of political leaders, the supports and helps from other countries and the European Union to build and link countries in the region through a cyber highway creates an opportunity for governments in the region to show their commitment to eGovernment.5 "With the support from different governments, resources (human capital, physical capital etc.) may pool to develop strategies for planning, implementation, monitoring and the modification of G2G (government-togovernment) communication within and between countries." (Ha \& Coghill, 2006: 119)

"Concerning economics, people with IT proficiency have better opportunities for employment since computer literacy is becoming a requirement for most industries in Serbia. Thus, people are motivated to learn computer skills. Time constraints are another motive to urge the public to adopt eServices" (Ha \& Coghill, 2006: 119). Most businesses that use eServices can save time and effort when shopping for public services online. Now, business competition between competitors is becoming more intensive. The internet "can help businesses to narrow the gaps between ordering, delivering and monitoring the flow of information" (Ha \& Coghill, 2006: 119), while the eGovernment could help to create a business friendly "e-space" for this.

Socially, new generation of internet users is emerging. They could help to improve the eGovernment and eServices. The only question is how to get involved this generation. ${ }^{6}$

\footnotetext{
5 See for example the Regional school of Public Administration (http://www.respaweb.eu/).

6 The project "e-School" is a good initiative (http://nasaskola.net/). Serbia needs more similar initiatives.
} 
Finally, the development of new technology applications (even on cell/smart phones) presents opportunities for better, cheaper and more efficient eServices.

\section{Threats}

Politically, cyber-terrorism emerges as a threat to eGovernment. For example, technological capabilities have greatly advanced and terrorists could use the web to strike critical infrastructure. Serbia is not having such threats, but it has to prepare, because it requires a lot of time, work force and technology to fix such cyber offences. The future developments have to prepare for these threats. Another threat is the change in government. The government must ensure through legal means the eGovernment's undisturbed development (need for stability in the leadership of the eGovernment project and planning for a long-term).

Security breaches are another problem for eGovernment. The weak data protection and security in the legal system and advanced technology make it easy for hackers to penetrate government websites. This will create insecurity among the administration authorities

"who then may not be willing to go online. For example, they may be unsure if their particulars are protected. [...] Internet and computer related crimes, such as hacking, fraud, spam, phishing or identity fraud and theft, would hinder the development of eGovernment. Since the one mode of online payment is by credit card, security becomes a major problem. If problems' relating to security and privacy often occurs, users could hesitate to give credit card details and thus may not want to use eServices." (Ha \& Coghill, 2006: 120)

In order to avoid these problems, careful management is needed. The question of security should be a task and not a threat.

An economic threat exists if increases of everyday life flow through to higher charges for broadband subscriptions of internet, which financially burden the users. To prevent this, it would be useful if the government takes into consideration the purchase and installation of common access points with appropriate support across the country.

"Social threats include the rapid development of telecommunication such as mobile and SMS technology." (Ha \& Coghill, 2006: 120) The lower cost of cell phones provides an incentive for people to switch from the internet to 
cell phones. News headlines are easier to reach via cell phones. Information about current affairs and carrying out some other activities is faster through cell phones rather than by using eServices. That is why the eGovernment plan of Serbia should include the question of cell phones (for instance development of - mobile - m-services), too.

The dependence of people on technology may produce adverse effect on people: serving technology, instead of technology serving people. (Ha \& Coghill, 2006). "For example, if users are not well equipped with IT skills and knowledge, it can take those hours to retrieve corrupted documents. Moreover, a proportion of Serbians may not have equal opportunity to access the internet there are not enough access points at libraries and community centers and this brings us back to the need of free terminals and motivated and well-prepared persons who are in the centre of the flow of information and a good role models in the local micro-societies.

The results of the analysis above already highlighted some major problems: what should take into a consideration during the development of a communication plan for the portal eUprava. The following table analyzes the portal, its relations and communication from the past. 
Table 2: SWOT and PEST analysis of the portal eUprava

\begin{tabular}{|c|c|c|c|c|}
\hline PEST / SWOT & Strength $(S)$ & Weaknesses (W) & Opportunities (O) & Threats $(\mathrm{T})$ \\
\hline \multirow{4}{*}{$\begin{array}{l}\text { Political aspect } \\
\text { (P) }\end{array}$} & Motivated people & $\begin{array}{l}\text { Lack of legal } \\
\text { framework }\end{array}$ & $\begin{array}{l}\text { First steps already } \\
\text { taken }\end{array}$ & $\begin{array}{l}\text { Some governmental } \\
\text { administrations (even } \\
\text { ministries) develop- } \\
\text { ing their own eAd- } \\
\text { ministration portal; } \\
\text { lack of cooperation }\end{array}$ \\
\hline & $\begin{array}{l}\text { First horizontal } \\
\text { linkages between } \\
\text { some administra- } \\
\text { tion authorities } \\
\text { have been made } \\
\end{array}$ & $\begin{array}{l}\text { Weak public au- } \\
\text { thority of eUprava }\end{array}$ & $\begin{array}{l}\text { Making govern- } \\
\text { ment and public } \\
\text { administration more } \\
\text { transparent }\end{array}$ & $\begin{array}{l}\text { Uncertain manage- } \\
\text { ment structure (the } \\
\text { portal is between two } \\
\text { ministries) }\end{array}$ \\
\hline & $\begin{array}{l}\text { Early (but in } \\
\text { some cases not } \\
\text { qualitative) } \\
\text { involvement of } \\
\text { many stakehold- } \\
\text { ers } \\
\end{array}$ & $\begin{array}{l}\text { Not all the stake- } \\
\text { holders engaged }\end{array}$ & $\begin{array}{l}\text { After comprehensive } \\
\text { development the } \\
\text { portal could be the } \\
\text { leading eGovernment } \\
\text { portal in the region }\end{array}$ & $\begin{array}{l}\text { Weak political } \\
\text { support behind the } \\
\text { portal }\end{array}$ \\
\hline & $\begin{array}{l}\text { Plans for the } \\
\text { mid-term devel- } \\
\text { opment (until } \\
\text { 2013) }\end{array}$ & $\begin{array}{l}\text { Limited un- } \\
\text { derstanding of } \\
\text { eUpravas role in } \\
\text { some ministries }\end{array}$ & $\begin{array}{l}\text { Revolution of the } \\
\text { public sector }\end{array}$ & $\begin{array}{l}\text { Public administra- } \\
\text { tors are requested to } \\
\text { change their work } \\
\text { habits }\end{array}$ \\
\hline \multirow{4}{*}{$\begin{array}{l}\text { Economic } \\
\text { aspect }(E)\end{array}$} & $\begin{array}{l}\text { Early involve- } \\
\text { ment of many } \\
\text { stakeholder }\end{array}$ & $\begin{array}{l}\text { Portal needs more } \\
\text { engaged economic } \\
\text { stakeholders }\end{array}$ & $\begin{array}{l}\text { Opportunity to edu- } \\
\text { cate the businesses on } \\
\text { eAdministration and } \\
\text { eServices }\end{array}$ & $\begin{array}{l}\text { Deepening of the } \\
\text { economic crisis }\end{array}$ \\
\hline & $\begin{array}{l}\text { First horizontal } \\
\text { linkages have } \\
\text { been made }\end{array}$ & $\begin{array}{l}\text { Delays in the pro- } \\
\text { cessing of services }\end{array}$ & $\begin{array}{l}\text { Could have a high } \\
\text { level of culture of } \\
\text { eAdministration }\end{array}$ & $\begin{array}{l}\text { Austerity measures } \\
\text { could result slower } \\
\text { spread of eUprava } \\
\text { portal }\end{array}$ \\
\hline & $\begin{array}{l}\text { Plans for the } \\
\text { mid-term devel- } \\
\text { opment }\end{array}$ & $\begin{array}{l}\text { Low number of } \\
\text { registered com- } \\
\text { panies }\end{array}$ & $\begin{array}{l}\text { Saving expensive } \\
\text { labor costs }\end{array}$ & $\begin{array}{l}\text { Weak economic } \\
\text { support behind the } \\
\text { portal }\end{array}$ \\
\hline & $\begin{array}{l}\text { Digital cer- } \\
\text { tificates for } \\
\text { identification } \\
\text { and electronic } \\
\text { signature on the } \\
\text { ID cards }\end{array}$ & ePayment & $\begin{array}{l}\text { No cash in hand, } \\
\text { only electronic bank- } \\
\text { ing }\end{array}$ & $\begin{array}{l}\text { Low support of } \\
\text { stakeholders to } \\
\text { eUprava }\end{array}$ \\
\hline
\end{tabular}




\begin{tabular}{|c|c|c|c|c|}
\hline PEST / SWOT & Strength $(S)$ & Weaknesses (W) & Opportunities (O) & Threats (T) \\
\hline \multirow{5}{*}{$\begin{array}{l}\text { Social aspect } \\
\text { (S) }\end{array}$} & $\begin{array}{l}\text { Growing number } \\
\text { of registered } \\
\text { users }\end{array}$ & $\begin{array}{l}\text { No real } \\
\text { one-stop-shop }\end{array}$ & $\begin{array}{l}\text { Opportunity to } \\
\text { educate the public on } \\
\text { eAdministration and } \\
\text { eServices }\end{array}$ & $\begin{array}{l}\text { No culture of eAd- } \\
\text { ministration }\end{array}$ \\
\hline & $\begin{array}{l}\text { Use of multilin- } \\
\text { gualism }\end{array}$ & $\begin{array}{l}\text { Level of multilin- } \\
\text { gualism }\end{array}$ & $\begin{array}{l}\text { Bridging the gap in } \\
\text { digital divide (with } \\
\text { education) }\end{array}$ & $\begin{array}{l}\text { Decelerating growth } \\
\text { in internet penetra- } \\
\text { tion }\end{array}$ \\
\hline & $\begin{array}{l}\text { Email and SMS } \\
\text { notifications }\end{array}$ & $\begin{array}{l}\text { No clear com- } \\
\text { munication and/or } \\
\text { promotion plan }\end{array}$ & $\begin{array}{l}\text { Free terminals and } \\
\text { eCounsellors }\end{array}$ & $\begin{array}{l}\text { Frustration of digi- } \\
\text { tally illiterate persons }\end{array}$ \\
\hline & $\begin{array}{l}\text { High use of ap- } \\
\text { pointment book- } \\
\text { ing function }\end{array}$ & $\begin{array}{l}\text { Limited un- } \\
\text { derstanding of } \\
\text { eUprava's role in } \\
\text { general public }\end{array}$ & $\begin{array}{l}\text { Developing a culture } \\
\text { of eAdministration }\end{array}$ & $\begin{array}{l}\text { Distrust in public } \\
\text { towards the portal }\end{array}$ \\
\hline & $\begin{array}{l}\text { Clear portal, } \\
\text { simple for use }\end{array}$ & $\begin{array}{l}\text { Small number of } \\
\text { services are in use }\end{array}$ & $\begin{array}{l}\text { Reducing citizen's } \\
\text { dependence on civil } \\
\text { servants }\end{array}$ & $\begin{array}{l}\text { Making the eAdmin- } \\
\text { istration mandatory } \\
\text { for the public (e.g. } \\
\text { with card readers) }\end{array}$ \\
\hline $\begin{array}{l}\text { Technological } \\
\text { aspect }(\mathrm{T})\end{array}$ & $\begin{array}{l}\text { Use of W3C } \\
\text { standards }\end{array}$ & $\begin{array}{l}\text { The transparency } \\
\text { of the portal }\end{array}$ & $\begin{array}{l}\text { Better and cheaper } \\
\text { eServices }\end{array}$ & $\begin{array}{l}\text { Electronic crisis, } \\
\text { computer viruses, } \\
\text { worms and computer } \\
\text { bugs }\end{array}$ \\
\hline
\end{tabular}

The table reflects only the main characteristics of the eUprava. The arrows are showing the interdependencies between the issues. We will further discuss these interdependencies in the next chapter, because they are crucial for the action plan explained in the section 4.9.

\section{Weaknesses and the threats of the portal}

The designed portal is viable. The strengths and the opportunities confirm this. Although the content is not rich, it can be extended anytime. Bigger problem is that the portal is not in touch with citizens: small number of registered citizens is on the portal. Good, new or redesigned products on the portal and promotion and communication strategy could help increasing the number of the public on the portal. First, we have to take a closer look to some characteristics of the portal eUprava before we outline a strategy. Second, we will further analyze the stakeholders of the portal, what we partly did during the SWOT and PEST analysis. 


\section{The business users and the citizen users}

Today the eUprava provides very small number of services for non-citizen users (G2B). Registration of all types of legal and physical entities works without a legal background, which is possible from legal point of view, because it can be handled as based on informed consent, however the fact that there is no real legal background behind the portal decreases the trust in a such entity.

The enterprises could be "good costumers" of the portal, because they could generate a higher turnover. One company always has some matters with the administration. Declarations, assertions, certificates, applications etc. are the documents what they need in their everyday life. While the citizens apply for birth, citizenship and other certificates - in good case - once in a lifetime, renew their ID cards or passports every 5-10 years, renew their vehicle registration every year. The citizen users of the portal would not generate real traffic on the portal and it is even questionable, whether is it worth to learn them for one time the electronic procedures (by the next usage it will be most probably different - improved). The business users are those who could generate traffic, and the citizens will be also familiar with the electronic processes through the "official" use. The enterprises need real services and reliable legal background.

Moreover, the enterprises are those entities where the government may require eAdministration. The prerequisite for this is to create and offer on the portal as many one-stop-shop administrations as can. Those employees, accountants, auditors and lawyers who will do the administration for their companies will be the experts of the eUprava; they could be the carriers of the eService and eAdministration culture in Serbia. They could educate their relatives and friends how to use the portal, also this is the reason why should not differ significantly the business part from the individuals part of the portal. Consequences of this are:

1. Need for more real one-stop-shop functions on the portal,

2. The logic of the business part and the individuals part of the portal should be similar,

3. It would be useful after the redesign of the services and introduction of new services for legal entities if some administrations of the enterprises would be mandatory to do online on the portal eUprava. 


\section{The transparency of the portal}

We would emphasize two elements under the transparency. The first is the legal embeddedness of the portal. Most of services on the eUprava are made by the mercy of the administrative bodies. If the administrative body had willingness, sources and time, they offered their - or some of their - services on the portal. Meantime, some of the administrative bodies are still creating their own eAdministration/eGovernment site. For instance, these bodies are Tax Administration, Serbian Business Registers Agency and National Employment Service, etc. This situation puts the eUprava portal among those sites, which are offering eGovernment services, but it does not make it into prominence portal. eUprava needs legal background. The portal should have clear role among the different portals, moreover, it should be "the" eGovernment portal according to law, and not one of the many eGovernment portals.

The second is the authentication, data protection and security. Generally, the public knows very little about the functioning of the portal eUprava. These elements should emphasize on the portal. The relevant ministry could help to establish the data protection and the security statement of the portal. Now only the User Guide contains some information about these elements, but it exists only in Cyrillic version (no English or other languages). The explanation of protection of personal data could build confidence among the citizens and this could result higher number in use of the portal. The portal should follow the recommendations of the EU, it should be committed to the privacy, and it should prove that the data from citizens would be safe in the hands of the portal.

\section{Horizontal relations}

The horizontal relations already mentioned in the previous, 4.4.2. part of this section. The portal eUprava builds on the equal relation of the administration. Although they are equal, the portal should become the "e-centre" of the administrations. This could be reach by law, but the operator of the portal shall also endeavor to build a good relationship with other administration bodies. This could help to implement the above-mentioned law; the other administrations would not feel the joining to eUprava as an extra load.

\footnotetext{
7 For example follow the recommendations of the European Commission - Article 29 working group on data protection (http://ec.europa.eu/justice/policies/privacy/workinggroup/wpdocs/index en.htm)
} 
It could be a problem, that the portal has no clear responsibility policy. What should happen if some services are unavailable, but the costumer has no time to go to the office, or a deadline is approaching? Who is responsible if the costumer claims that he sends the document, but the authority does not see it? These are the questions for the law and these legal regulations should be adopted as soon as possible.

It is also important to make obvious to other horizontal partners that the eUprava portal is the solution for the future and building a total separate portal is worthless. On the other hand, the total centralization of eServices is impossible; some functions will always remain separate (for example some issues related to labor administration). The clear and transparent authentication, data protection and security would help in this task of the portal, as well. Building trust with public also means building trust with horizontal bodies.

\section{ePayment}

The payment and payment methods are important elements of an eGovernment portal. One of the newest functions of eUprava portal is ePayment. There are two types of issues in this relation. The first issue is that the portal accepts only DINA cards. For the involvement of the big international payment providers, it would be necessary to solve the issue of the transparent coverage of the commissions. Offering ePayment with cards of more than one provider (including the big international payment systems) could generate higher number of portal users.

The second issue is the information flow. At the current level, when there is no online electronic service it is not big obstacle, however for real online eGovernment services the service provider has to be aware of the information on the payment. This information necessitates serious improvement by all concerned service providers.

\section{Multilingualism}

Serbia has more than 10 minorities. The eUprava portal has six translations, five in the languages of minorities (Croatian, Hungarian, Romanian, Ruthenian and Slovakian) and one in English. The problems with non-Serbian versions are that they are not complete translations. For instance, in every language the last two links among the "Individuals" part are in Serbian Cyrillic letters (Persons with disabilities and Human rights). The same is with the Business 
section (Cadastre and Energy). If the portal is committed to multilingualism, it has to have complete translations of the portal. The same applies for the User Guide, which is now only in Serbian Cyrillic alphabet (and it is not available in English version). This is strange, because the Help function has translations to other languages, and it is more or less the same as the User Guide. To have fully functioning portal the translations should be complete in every language. The portal would attract more users and it would be a good PR tool in the hand of the operator.

It might be worth to consider making a German language version of the portal, too. Many German enterprises are in Serbia and many Serbians are working in Germany. One can easily imagine that the German version of the portal would be more popular than the English one.

\section{Communication attempts from the past}

The portal eUprava has/had promotion gifts (pen drives, T-shirts, mugs, notebooks etc.). These are important tools of passive communication. However, more important are those, which we can hardly find. For instance, the user name "PortaleUprava" uploaded three videos to the YouTube video sharing site two years ago. ${ }^{8}$ One is on performing services on eUprava portal; the second is on $\log$ in to the portal and the third is on electronic certificates of the post. These videos are in use on the portal, when a user needs help, for instance when she or he needs help with the log in the video can serve as a guide. The only problem is that this video is not a promotion or communication tool of the portal. Similar is the situation with the Twitter account of eUprava. ${ }^{9}$ In the eye of internet users, these communication channels are for help desk functions and not for promotion purposes.

The only actual communication/promotion channel is the Facebook channel of the portal. ${ }^{10}$ News and information about the happenings of Serbian eGovernment and the portal eUprava are available here. However, we must not forget that Facebook is popular in Serbia, but not all the internet users are on this channel and even not all registered Serbian Facebook users are following this channel (the eUprava Facebook page has a little less than 1,700 followers).

\footnotetext{
8 http://www.youtube.com/user/PortaleUprava?feature=watch.

9 https://twitter.com/eUprava.

${ }^{10} \mathrm{http}: / /$ www.facebook.com/eUprava.
} 
It is necessary to rethink the "help desk channels" and communication channels of the portal, and to separate these in order to have more targeted promotion channels for the portal.

\section{The stakeholder identification and analysis}

We already differentiated some of the stakeholders during the SWOT and PEST analysis. Now we have to set the priority among the stakeholders. This will mean the identification of the audience addressed in the communication plan. The audience consists of the persons that will receive the messages as well as any possible affected parties by the delivered messages.

\section{High priority stakeholders are:}

- Host agencies (Directorate for Digital Agenda - Ministry of Foreign and Internal Trade and Telecommunications). eGovernment development and role of eUprava communicated to host agencies of services to ensure smooth collaboration. It is essential to communicate success stories.

- Political leadership. Continuous communication is necessary to ensure the support for eUprava throughout all stages, from the beginning to the enactment.

- Users of government services (non-registered users or offline users). It is necessary to learn them and understand their needs. Introduction to the services of eUprava, quick and satisfying reaction to their needs and confidence building are the most urgent agendas.

Medium priority stakeholders are:

- Users of eUprava services (registered users or online users). Strengthen their commitment to eUprava.

- Government agencies not involved in eGovernment yet. All ministries, government agencies and administrations that provide public services need to join the eUprava. The success stories could be good rallying calls.

Low priority stakeholders are:

- Potential business partners. (These are companies willing to offer public private partnership in implementing the goals and aims of eUprava portal.) 
No need for active communication, passive communication is enough. Active communication need only upon expressed interest of companies or after the improvement of the portal.

Three key questions to ask from every stakeholder are:

1. What do we need from them?

2. Where are they standing?

3. What do they need from us?

The following table will answer these questions:

\section{Table 3: Stakeholder analysis}

\begin{tabular}{|c|c|c|c|}
\hline Stakeholders & $\begin{array}{l}\text { What do we need } \\
\text { from them? }\end{array}$ & $\begin{array}{l}\text { Where are } \\
\text { they standing? }\end{array}$ & $\begin{array}{l}\text { What do they need } \\
\text { from us? }\end{array}$ \\
\hline \multirow[b]{2}{*}{ Host agencies } & $\begin{array}{l}\text { Buy-in for redesign of } \\
\text { services (if needed) }\end{array}$ & $\begin{array}{l}\text { Basic understanding } \\
\text { of eUprava }\end{array}$ & $\begin{array}{l}\text { Clear communication of } \\
\text { support from leadership } \\
\text { level }\end{array}$ \\
\hline & $\begin{array}{l}\text { Readiness to imple- } \\
\text { ment and roll out } \\
\text { agreed redesign of } \\
\text { eServices (if needed) }\end{array}$ & $\begin{array}{l}\text { Basic understand- } \\
\text { ing of eGovernment } \\
\text { programmes from } \\
\text { abroad }\end{array}$ & $\begin{array}{l}\text { Clarification on mode of } \\
\text { collaboration }\end{array}$ \\
\hline \multirow[b]{2}{*}{$\begin{array}{l}\text { Political lead- } \\
\text { ership }\end{array}$} & $\begin{array}{l}\text { Clear communication } \\
\text { of support }\end{array}$ & $\begin{array}{l}\text { Awareness of eU- } \\
\text { prava }\end{array}$ & $\begin{array}{l}\text { Regular updates on status } \\
\text { of eUprava development }\end{array}$ \\
\hline & $\begin{array}{l}\text { Legislative and legal } \\
\text { background }\end{array}$ & $\begin{array}{l}\text { Only sporadically } \\
\text { involved in actively } \\
\text { building support } \\
\text { within government } \\
\text { agencies }\end{array}$ & $\begin{array}{l}\text { Information on whom } \\
\text { to contact at what stages } \\
\text { to express support and } \\
\text { urgency }\end{array}$ \\
\hline
\end{tabular}




\begin{tabular}{|c|c|c|c|}
\hline Stakeholders & $\begin{array}{l}\text { What do we need } \\
\text { from them? }\end{array}$ & $\begin{array}{l}\text { Where are } \\
\text { they standing? }\end{array}$ & $\begin{array}{l}\text { What do they need } \\
\text { from us? }\end{array}$ \\
\hline \multirow{2}{*}{$\begin{array}{l}\text { Users of } \\
\text { government } \\
\text { services }\end{array}$} & $\begin{array}{l}\text { Perception of eGovern- } \\
\text { ment as important }\end{array}$ & $\begin{array}{l}\text { Hardly any aware- } \\
\text { ness of eUprava }\end{array}$ & $\begin{array}{l}\text { Information on impor- } \\
\text { tance of eGovernment and } \\
\text { eUprava }\end{array}$ \\
\hline & $\begin{array}{l}\text { Strong demand for new } \\
\text { eServices }\end{array}$ & $\begin{array}{l}\text { Sceptical about } \\
\text { internet and/or low } \\
\text { digital literacy }\end{array}$ & $\begin{array}{l}\text { Education, building a } \\
\text { digital culture of using } \\
\text { eGovernment }\end{array}$ \\
\hline \multirow{2}{*}{$\begin{array}{l}\text { Users of eUp- } \\
\text { rava services }\end{array}$} & $\begin{array}{l}\text { Good communication } \\
\text { of the portal }\end{array}$ & $\begin{array}{l}\text { Awareness of Serbian } \\
\text { eGovernment devel- } \\
\text { opment }\end{array}$ & $\begin{array}{l}\text { Simple functions, easy ac- } \\
\text { cess to the portal }\end{array}$ \\
\hline & $\begin{array}{l}\text { Feedbacks about the } \\
\text { portal }\end{array}$ & Active internet users & $\begin{array}{l}\text { Transparent processes of } \\
\text { eServices }\end{array}$ \\
\hline \multirow{2}{*}{$\begin{array}{l}\text { Government } \\
\text { agencies not } \\
\text { involved in } \\
\text { eGovernment } \\
\text { yet }\end{array}$} & $\begin{array}{l}\text { Basic understanding of } \\
\text { eGovernment effort }\end{array}$ & $\begin{array}{l}\text { Sceptical about rede- } \\
\text { signing services }\end{array}$ & $\begin{array}{l}\text { Information on benefits } \\
\text { of joining eGovernment } \\
\text { effort }\end{array}$ \\
\hline & Readiness to join & $\begin{array}{l}\text { Basic awareness of } \\
\text { Serbian eGovern- } \\
\text { ment development }\end{array}$ & Success stories \\
\hline \multirow{2}{*}{$\begin{array}{l}\text { Potential busi- } \\
\text { ness partners }\end{array}$} & $\begin{array}{l}\text { Active approach } \\
\text { towards government if } \\
\text { willing to offer coop- } \\
\text { eration }\end{array}$ & $\begin{array}{l}\text { Interest in coopera- } \\
\text { tion with govern- } \\
\text { ment }\end{array}$ & $\begin{array}{l}\text { Information on benefits } \\
\text { of joining eGovernment } \\
\text { effort }\end{array}$ \\
\hline & $\begin{array}{l}\text { Enabling faster imple- } \\
\text { mentation of eUprava } \\
\text { projects }\end{array}$ & $\begin{array}{l}\text { Basic awareness of } \\
\text { Serbian eGovern- } \\
\text { ment development }\end{array}$ & Success stories \\
\hline
\end{tabular}

\section{Conclusion}

It is obvious that the portal eUprava has low media awareness, but it seems that the portal's operators are uncertain and cautious when it comes to marketing communication. The acceptable reason for this could be that the service is not perfect and it is not worth of promotion. We did not see active and conscious PR from the portal. It seems indispensable that PR should be a tool for 
educational purposes to enhance public awareness and overcome the differences between North and South Serbia. The same is the situation with marketing communication; from an actual starting point, an action plan could outline the strategy how to increase eUprava's visibility and the traffic on the portal.

This paper cannot give ultimate answers to the desirable communication of the portal eUprava, but its recommendations for eGovernment portal and promotion plan are good basis for a Communication Strategy plan. The organization behind the portal has weak marketing communication and PR competence. In order to be successful in promotion and communication of the portal increased attention should be paid to the online and offline audience. One person should be appointed who could be responsible for the Communication Strategy and who could manage the eUprava portal's promotion campaigns. 
Difficulties for eGovernment promotion in Serbia:

The analysis of eUprava Portal

Norbert Merkovity

\section{References}

Barber, B. R. (1984). Strong Democracy: Participatory Politics for a New Age. Berkeley: University of California Press.

Borras, J. (2012). The OASIS Transformational Government Framework. European Journal of ePractice, 15, 26-51.

van Dijk, J. A. G. M. (2005). The Deepening Divide: Inequality in the Information Society. Thousand Oaks: Sage.

Dunleavy, P., Margetts, H., Bastow, S. \& Tinkler, J. (2006). Digital Era Governance: IT Corporations, the State and E-Government. Oxford: Oxford University Press.

Dunleavy, P. \& Margetts, H. (2010). 'The second wave of digital era governance', paper presented at American Political Science Association Conference, 4 September 2010, Washington.

EC - European Commission (2009). Ministerial Declaration on eGovernment Malmö. Accessed 28/02/2013. URL: https://ec.europa.eu/digital-agenda/ sites/digital-agenda/files/ministerial-declaration-on-egovernment-malmo. pdf.

EC - European Commission (2010). The European eGovernment Action Plan 2011-2015: Harnessing ICT to promote smart, sustainable \& innovative Government, Brussels. Accessed 28.02.2013. URL: https://ec.europa.eu/digitalagenda/en/european-egovernment-action-plan-2011-2015.

Georgiou, M., Haddon, L., Helsper, E. \& Wang, Y. (2010). Existential field 8: Special Focus Pieces. In Family Platform Project. London: LSE.

Ha, T. T. H. \& Coghill, K. A. (2006). E-government in Singapore - A SWOT and PEST analysis. Asia-Pacific Social Science Review, 6(2), 103-130.

Helsper, E. J. (2012). A Corresponding Fields Model for the Links between Social and Digital Exclusion. Communication Theory, 22(4), 403-426.

Karabulut, A., Braet, D., Lindstrom, D. \& Niederhauser, D. (2009). Student Level of Commitment and Engagement with Ning as a Learning Management System. In Maddux, C. D. (ed.), Research Highlights in Technology and Teacher Education 2009. Chesapeake: SITE, pp. 125-132.

Livingstone, S. \& Helsper, E. J. (2010). Balancing Opportunities and Risks in Teenagers' Use of the Internet: The Role of Online Skills and Family Context. New Media \& Society, 12(2), 309-329. 
Merkovity, N. (2011). A New Public Managmenttől a Digital Era Governanceig: Kormányzás paradigmák a nyolcvanas évektől a millenniumi évekig [From New Public Management to Digital Era Governance: Governance paradigms from the eighties until the Millennium years]. De Iurisprudentia et Iure Publico, Jog-és Politikatudományi Folyóirat, 5(3), 100-120.

Mominó, J. M. \& Meneses, J. (2007). Digital Inequalities in Children and Young People: A Technological Matter? In 2nd International Convention on New Millennium Learners: Schools, ICT and Learning. Florence (Italy), 2007.

Mumtaz, S. (2001). Children's Enjoyment and Perception of Computer Use in the Home and the School. Computers in Education, 36(4), 347-362.

Pew Internet (2012). Digital Differences. Accessed 23.02.2013. URL: http:// pewinternet.org/Reports/2012/Digital-differences.aspx.

Prieto-Martín, P., de Marcos, L. \& Martínez, J. J. (2012). The E-(R)evolution will not be Funded. European Journal of ePractice, 15, 62-89.

Schlosser, A. E., Shavitt, S., \& Kanfer, A. (1999). Survey of Internet Users' Attitudes toward Internet Advertising. Journal of Interactive Marketing, 13(3), $34-54$.

Statistical Office of the Republic of Serbia (2011). Usage of Information - Communication Technologies in the Republic of Serbia, 2011. Accessed 01.03.2013. URL: http://webrzs.stat.gov.rs/WebSite/public/PublicationView.aspx?pKey $=41 \&$ pLevel $=1 \&$ pubType $=2 \&$ pubKey $=728$.

Statistical Office of the Republic of Serbia (2012). Usage of Information Communication Technologies in the Republic of Serbia, 2012. Accessed 01.03.2013. URL: http://webrzs.stat.gov.rs/WebSite/repository/documents/00/00/78/89/Saopstenje_2012_engl.pdf.

Szittner, K. (2011). e-Ügyintézés Magyarországon [e-Administration in Hungary]. Budapest: e-Government Alapítvány.

UN - United Nations (2012). E-Government Survey 2012: E-Government for the People. New York: United Nations.

Witte, J. C. \& Mannon, S. E. (2010). The internet and social inequalities New York: Routledge.

Zillien, N. \& Hargittai, E. (2009). Digital Distinction: Status-specific Types of Internet Usage. Social Science Quarterly, 90(2), 274-291. 